Chapter 8

\title{
Redefining Androgen Receptor Function: Clinical Implications in Understanding Prostate Cancer Progression and Therapeutic Resistance
}

\author{
Miltiadis Paliouras, Carlos Alvarado and Mark Trifiro \\ Additional information is available at the end of the chapter
}

http://dx.doi.org/10.5772/64392

\begin{abstract}
The current description of the function of the human androgen receptor (AR), as a transcription factor directing androgen responsive gene expression, is limited in scope and thus is unable to account for the varied cellular and physiological transformation observed in the development and progression of prostate cancer (CaP). The chapter will focus on four important aspects of $\mathrm{AR}$ and $\mathrm{CaP}$ investigations: (1) a description of $\mathrm{AR}$ somatic mutations and the perils of AR-directed therapeutics; (2) our characterization of AR protein interactors that have imbued new functional properties for AR linked to prostatic disease; (3) review of the advances made and shortcomings of AR mouse models in describing $\mathrm{CaP}$ onset and progression; and (4) speculate as to the mechanisms by which new mutations can originate and initiate disease onset.
\end{abstract}

Keywords: androgen receptor, prostate cancer, somatic mutations, interactome, mouse models, gain-of-function properties, therapeutic resistance, mutational landscape

\section{Introduction}

Advanced DNA sequencing technology and the information garnered from it has ushered a new era especially poignant to the genetics of cancer. In present and next-generation sequencing methodologies in conjunction with the establishment of consortiums (COSMIC: and TCGA: http://cancer.sanger.ac.uk/cosmic and TCGA: tcga-data.nci.nih.gov/tcga), whose major efforts are to characterize the cancer genome of a large number of cancers in a systematic fashion, 
modern cancergenetics has come to theforefront. These "mutationallandscapes" haveredefined cancer genetics and will dramatically direct cancer research for decades to come [1-10].

Modern cancer genetics has now unequivocally demonstrated extensive somatic DNA alterations many times more than previously envisioned [11-14]. Although dependent on specific tumor types, somatic mutations are in the order of tens of thousands; the present-day technology most likely underestimates the true number of mutations as mutations occurring in less than $10-15 \%$ of cells cannot be detected. Advances in single-cell DNA analysis now suggest that indeed many more mutations do exist at in smaller number of cells $[15,16]$. More importantly, there is an advanced degree of intertumoral heterogeneity where the same tumor types in different patients share only a few DNA alterations [17, 18]. As well intratumoral heterogeneity is extensive, where in the same individual's tumor, there are many different DNA alterations in specific subpopulation of cells. Also, the DNA sequence defined for a specific tumor is a composite sequence, where an amalgamation of small "bits" of DNA sequence, whose origins are from many different cells, is aligned to generate the "tumor" DNA genome; where in reality, no individual tumor cell most likely has that defined sequence.

Cataloging sequence alterations are the mainstay on present-day consortiums, important in defining tumor heterogeneity and also to help understand what potential effects these alterations may have on neoplastic initiation and evolution. Many mutations evoke specific gain of function properties implying driver capabilities [19]. The true understanding of these mutations is an extremely daunting task; defining these new gain-of-function properties is presently done in the context of the somatically mutated protein in question without any of the mutations of other proteins present; to truly account for real gain of function properties would require the presence of all mutations. The possible permutations and combinations of tens-of-thousands mutations on many proteins and the outcome on cellular physiology are incomprehensible even more so when cell-to-cell functionality is implied.

Nonetheless, the establishment of mutational landscape databases with defining characteristics, in conjunction with the required systems biology and network analysis, has led to many insights in tumor dynamics. What has been lacking in cancer fundamentals are investigations addressing the origins of these vastly accrued DNA alterations.

Cancer hallmarks defined by Hanahan and Weinberg have more or less been universally agreed upon and now include "enabling hallmarks," those hallmarks that are not descriptive in nature but imply distinct contributions to neoplastic development [20]. One of these enabling hallmarks is referred to as genomic instability. A more apt description would be the connotation of mutator phenotype, originally described by Lawrence Loeb [21-23]. Briefly, the mutator phenotype is a trait shared by all cancer cells that endow cancer cells with the ability to create or enhance new and constant DNA alterations. This hallmark gives neoplastic cells, a constant source of new mutations allowing the genetic background to become widely disparate. Such cellular genetic diversity in turn allows for extreme selection processes to dictate tumoral evolution; selection processes are multiple: microenvironment on tumor cells, tumor cells on the microenvironment, and tumor cells on other tumor cells. 
The origins of tumor DNA alterations are indeed critical. Therefore, it is hard to imagine that a tumor and tumor evolution can exist without any DNA alterations. Mutational load directly impacts tumor aggressiveness and metastatic potential. Understanding the origins of somatic DNA alterations is now fundamental to the understanding of tumor initiation and evolution, and the extent of DNA alterations is most likely more critical than the actual single definition and characterization of specific DNA alterations given the tremendous heterogeneity that exists.

\section{Somatic mutations and prostate cancer}

Prostate cancer $(\mathrm{CaP})$ in many ways is unique. It is extremely common; as much as $50 \%$ of men will have CaP above the age of 55 and increases in incidence afterwards [24]. It is for the most part slow growing and only in a small percentage can develop advanced and life-threatening disease but still represents a significant number of individuals. However, due to the high incidence rates for $\mathrm{CaP}$ and the highly variable and unpredictable effects on morbidity and mortality, $\mathrm{CaP}$ is extremely vulnerable to over diagnosis (as aided by screening advocates) and thus overtreatment $[25,26]$. Treatment regimens have been extremely controversial with the no clear benefits of endocrine manipulation in early disease; most likely, the era of antiandrogens or androgen deprivation therapy (ADT) in early disease will not be adhered to, the treatment of which may have provoked more aggressive disease and linked to selecting out very worrisome gain-of-function androgen receptor (AR) mutations [27-29]. Surgical prostatectomy remains the only curative procedure if the disease was localized to the prostate at the time of surgery.

$\mathrm{CaP}$ is universally multifocal and is uniformly associated with hypertrophy or hyperplasia. Its pathological scoring (Gleason) is based on the fact that multiple lesions coexist and, by itself, is solely used to assess overall staging [30]. Multifocal cancers are typically genetic in nature, associated with DNA repair deficiencies and somatic loss of heterozygosity. The best example of endocrine genetic cancers is MEN2 syndrome that has been now well studied in all age groups and dramatically displays the hypertrophy to hyperplasia to frank carcinoma evolution [31]. There is no obvious related gene candidate in multifocal CaP.

\subsection{Androgen receptor}

The X-linked AR protein is a member of the nuclear receptor superfamily [32,33]. It is a ligandinducible protein containing a polymorphic N-terminal region, a central DNA-binding domain (DBD), and a C-terminal ligand-binding domain (LBD) [34-36]. Although the AR gene is classically not associated with direct DNA maintenance, it is a single allele (loss of heterozygosity is not a prerequisite) and remains the most prominent candidate directing $\mathrm{CaP}$ initiation and evolutions. Hypogonadal individuals with low levels of $17 \mathrm{C}$ steroids or with elements of androgen receptor (AR) deficiency, $\mathrm{CaP}$, are extremely rare. Most if not all molecular endocrinological studies of $\mathrm{CaP}$ implement the $\mathrm{AR} g$ as being a pivotal player in $\mathrm{CaP}$. In all CaP, AR is highly mutated (androgendb.mcgill.ca) [37-42]. The most recent $\mathrm{CaP}$ 
mutational landscape is very comprehensive and is the new reference for mutational analysis of genes in both initial disease and more advanced disease [39]. In this study, AR remains the most consistent altered gene and is the earliest gene to be altered in localized diseases: AR gene amplifications is then followed by AR splice variants and AR missense mutations, but these alterations are hard pressed to explain multifocality. Other somatic mutations found include AR-associated proteins (ETS fusions, FOXA1, ZBTB16, NCOR1, NCOR2); PIK3 pathway PIK3CA, (PIK3CB, PIK3R1, AKT1); DNA repair (APC, BRCA2); and WNT signaling (RNF43); Cell cycle (RB1) [39].

\subsection{AR and the CAG polymorphic tract}

The AR gene has an extremely rare attribute. A polymorphic pure uninterrupted CAG tract in exon 1 is present coding for a polyglutamine tract in the N-terminus of the AR. This tract varies in length in individuals $(n=12-31)$, and tract length also varies racially [43-49]. This tract also has small but very important effect on AR functionality: smaller length polyglutamine tract ARs have more transcriptionally prowess [50]. The fundamental explanation for the presence of the AR polyglutamine tract within the AR protein itself is not known.

AR CAG tracts are unique to primates and are uninterrupted in almost all species (the exception being mice). It is interesting that humans vs. other primates have the longest tract and thus are the most unstable.

AR CAG tracts are unique to mammals and are uninterrupted in almost all species (the exception being mice) [34,51]. Another trait related to all trinucleotide repeats is their inherent inability to remain stable; thus, AR CAG tract lengths are known to change in length somatically in various tissues including primary gonadal tissue $[52,53]$. It is interesting that humans vs. other primates have the longest tract and thus are the most unstable. The instability exists at two levels: at cell division with DNA replication and more importantly with AR transcription by the transcription excision repair machinery. Instability is usually biased toward expansion rather than contraction (2:1).

In a study of $\mathrm{CaP}$ and $\mathrm{AR}$ CAG tract instability, AR CAG tract instability existed in normal tissue to a certain degree but was very much enhanced in adjacent $\mathrm{CaP}$ tissue [52,54]. The CAG tract lengths varied from one foci of $\mathrm{CaP}$ to another foci of $\mathrm{CaP}$ in the same patient. The instability of the AR CAG tract is many orders of magnitude more than stable random DNA sequence and approaches error rates seen in DNA repair deficiency states. It thus remains a solid candidate for the gene that accounts for the multifocality of CaP. In brief, those cells that undergo the largest AR CAG tract contraction are the most active AR. These cells in turn through overactive AR pathways will provoke new DNA alterations and thus are ordained as a mutator phenotype.

\subsection{AR somatic mutations}

It has clear involvement in distinct diseases due to due well-characterized inherited lossof-function or somatic acquired gain-of-function mutations. The one same protein with diverse-heterogeneous mutations, each with clear phenotypes, offers unique complementary 
structure-functional studies. Exploiting the AR mutational properties found in individuals with androgen resistance syndromes (loss-of-function AR) or CaP (gain-of-function AR), in conjunction with receptor kinetic studies, molecular biology, advanced dynamic structural modeling, and proteomic-coupled network analyses studies, has described many fundamental and new processes to account for disease processes [55-59].

Given the central role that AR has in prostate biology, it is not unexpected that somatic $A R$ mutations may be selected for, adding to the $\mathrm{CaP}$ repertoire powerful new functions provoking neoplastic advancement [52, 54, 60, 61] (Figure 1). Recent studies in support of initial studies have again demonstrated that although most advanced prostatic cancers are uniformly androgen independent, the AR is still a very important contributor to the more progressive fatal disorder [62, 63]. Nearly, all "androgen-independent" or "castrate-resistant" prostatic tumors express high levels of AR, and levels are predictive of progressive disease [64, 65]. Indeed, as many as one-third of tumors exhibit AR gene amplification [66] and AR somatic prostate missense mutations and splice variants are well documented [38, 67, 68]. A number of somatic CaP AR (e.g., T877A) mutants have unique gain-of-function properties; they can bind several classes of steroids promiscuously with subsequent transactivation, be hyperactivated by normal ligands [69, 70] or be constitutively active without ligand [71]. Even more surprising is that anti-androgen treatments [e.g., flutamide, cyproterone acetate (CPA) or bicalutamide, and even the latest generation of anti-androgens (enzalutamide)] have selected out specific somatic AR gene $(A R)$ mutations [72-75]. Missense mutations also have other related gain of functions beyond their relaxed ligand-binding parameters; normally ligandbinding promotes a dramatic conformation change inducing helix 12 movement creating a new co-activator interacting site. In T877A, helix 12 is slightly misplaced and alters the coactivator binding where co-activator binding motifs preferences are changed. As well another gain of function property is manipulated that is AR N-C-terminal interactions are favored.

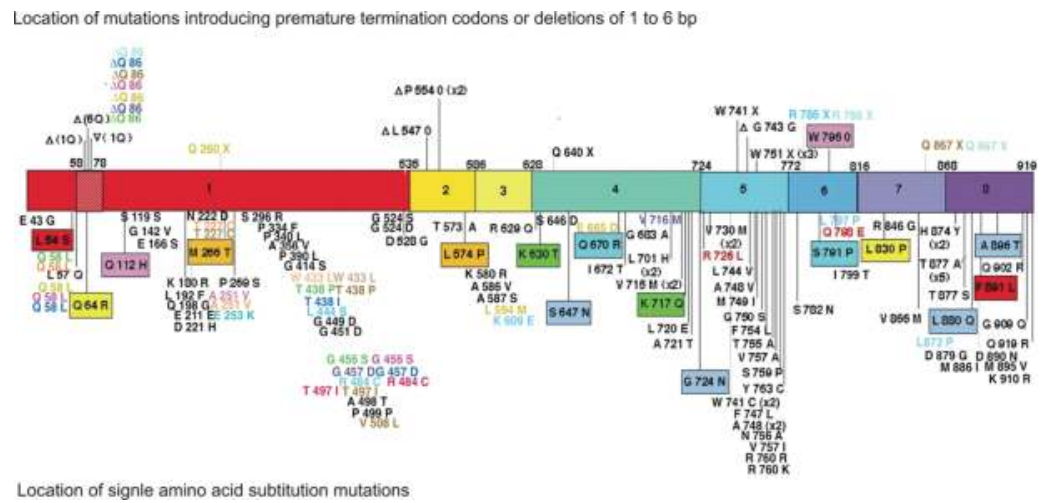

Figure 1. Schematic illustration of cataloged AR Somatic Mutations from the androgen receptor database. Mutations illustrated with the same color were present in the same cancer specimen. Mutations in red were found in the germline (image is courtesy of http://www.androgenbd.mcgill.ca">www.androgenbd.mcgill.ca, with permission from Dr. Mark Trifiro) [37]. 
Thus, any somatic mutated AR most likely will inherit multiple new functions, which can affect the whole AR complex itself.

In advanced $\mathrm{CaP}$, new AR variants have been found (Figure 2). AR-V7 and ARv567es splice variants have an intact NTD and DBD. The AR-V7 splice variant excludes exon 4 through 8 , resulting in a deletion of the LBD and the hinge regions, whereas ARv567es excludes exons 5 through 7 creating a LBD deletion; thus, these variants display "constitutive" ligand-independent transcriptional activity. It has been observed for many years that steroid receptor Cterminal truncated variants have constitutive activity; thus, in full-length steroid receptors, the presence of the C-terminal domains acts as a functional repressor whereupon ligand binding alleviates C-terminal repression.

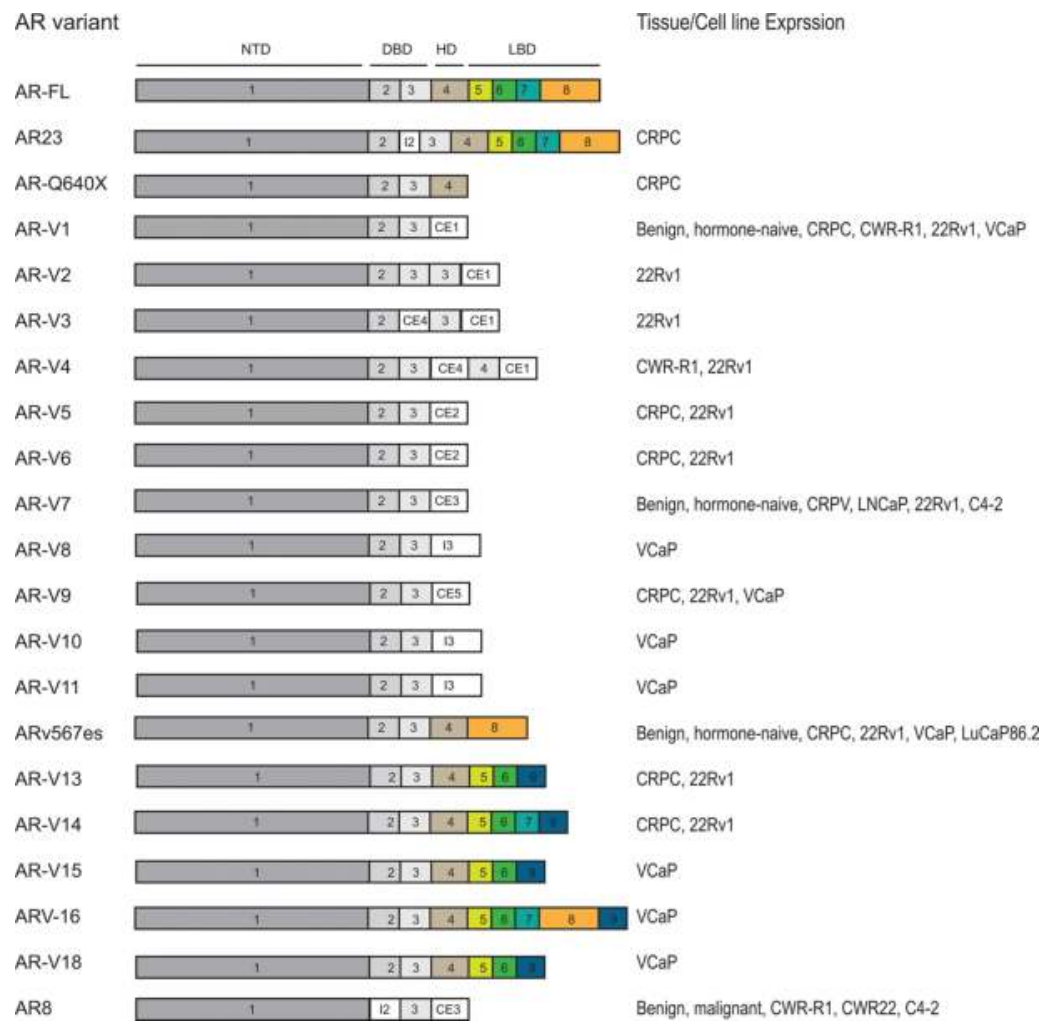

Figure 2. Schematic illustration of AR truncated and splice variants.

The repressive AR splice variants differ significantly from full-length AR in their transcriptional programs and subcellular localization [76, 77], implying different potential functions from wild-type AR (AR-WT). In an analysis of 46 castration-resistant prostate cancers (CRPCs), 80\% expressed full-length AR, 73\% expressed ARv567es and AR-V7; furthermore, 20\% of 
metastatic cases expressed ARv567es solely [78]. Western blot analysis appears to reveal that AR splice variants are also expressed in a number of different prostatic cancer cell lines [79]; however, it is not quite clear whether these variants are actually active or possess any of the attributed "constitutive" activity. Attention has also been given to the molecular mechanism by which these splice variants may arise. One hypothesis asserts that genomic rearrangements is one mechanism $[80,81]$, which maybe a valid means for established and immortalized cells lines, but more difficult to account for in a progressive disorder. Such a precise process for DNA deletion/rearrangement to independently and exactly occur so many times to result in the expression of these variants is very unlikely. Most recently, a more valid mechanism has been put forward that involved the overexpression of specific RNA splicing factors, U2AF65 and ASF/SF2, influenced the expression of AR-V7 splice variant in CaP cell lines [82]. Alternative RNA splicing has been shown to change during disease progression, and thus, the expression of specific RNA splicing factors during different stages of disease could more adequately account for the both frequency and temporal incidences of these AR variants. Alternative RNA splicing can also be considered another degree of added genetic heterogeneity to evolving neoplasias [83-86].

These gain of functions can extend to other facets of AR activity, namely the ability to attract different interactors or interplay with other pathways and possibly target different genes; these diverse gain-of-function attributes are likely to be manifested by a changed constitution of mutant AR complexes, which may well be cell and ligand specific and lend to the molecular pathological processes. Thus, cumulative analysis still supports the AR as a pivotal role player in prostate cell tumor biology, as it plays a fundamental and decisive role in prostate cell biology including very important prostate cell metabolism; what is left to be assessed is what aspect of wt or mutant AR functionality promotes directly or indirectly the mutator phenotype.

\section{AR protein complexes: contributors to $\mathrm{CaP}$ progression}

Somatic gain-of-function mutations allow neoplastic cells to acquire new properties that can aid the cancerous cells in finding new avenues for progression to more advanced disease. A multitude of AR gain-of-function attributes are likely to exist and most probably reflected in the composition of the AR interactome. As such, many proteins have been identified that interact with the AR and collaborate with it to execute its transcriptional program [87-89]. These observations suggest that the interplay between the AR, its associated interactors, and specific transcription factors can be selective and very dynamic [37, 58, 59, 87, 89]. All together, these findings also point to the complexity of the AR-interacting protein unit, suggesting that many functions of the AR are beyond our current understanding. Furthermore, the great functional diversity of the components of AR complexes exemplifies the intricate nature of protein-protein interactions associated with generating the appropriate AR biological output, and that mutant $\mathrm{CaP}$ ARs may have a their own unique ability to define new interactions. Therefore, the functional effect of AR needs to be investigated and show that certain AR properties, through protein-protein interactions can confer a growth advantage to cells. To do so, one would need to take into consideration a number of factors: (1) mutational status of the 
protein; (2) ligand status; (3) an amendable technology to assess protein-protein interactions; and (4) an encompassing process by which to analyze the data that would provide information on ontological function and most importantly clinical relevancy.

\subsection{AR protein isolation methodology}

To date, several techniques have been employed to isolate AR protein complexes including two-hybrid screens and GST pull-downs; however, several limitations have been an obstacle to isolating complexes in their natural cellular environment. First, previous approaches have either used yeast or bacterial systems [90-92]. One shortcoming of these systems is that fulllength AR cannot be expressed; therefore, only $\mathrm{N}$ - or C-terminal portions or specific AR domains have only been used. Second, within these systems, the use of a truncated AR, folding, and post-translationally modifications issues arise. Finally, the single most critical aspect of charactering any protein complex, for AR maintaining ligand binding, to the receptor during the isolation process, ensures an "active" complex is isolated. Therefore, our laboratory has developed a mammalian tissue cell culture expression and purification system that retains the ability of AR to maintain its ligand-binding activity [93,94]. The purification method employed by the following methodology ensures up to $90 \%$ of labeled-androgen ligand is still bound to the AR following fractionation. We therefore have the ability to capture both cytoplasmic and nuclear ARs under physiological conditions, with excellent recovery, that demonstrate measurable hormone binding even in in vitro conditions. We then have undertaken the process of purifying a number of AR complexes: (1) OCAG-AR, T877A-AR, WT-AR, in the presence or absence of the synthetic androgen mibolerone (MB) [59]; (2) T877A-AR, in the presence of a panel of hormone ligands (DHT, MB, testosterone, R1881, estradiol, dexamethasone, progesterone, and cyproterone acetate) [58]; (3) AR-V7 and ARv567es (Paliouras and Trifiro, unpublished data). We have been able to confirm the purification of our complexes by assessing known AR interactors [59]. However, to truly define the spectrum of proteins in the AR complexes, a more robust methodology and platform was needed, and as such, mass spectrometry approach was employed. Data generated by mass spectrometry were then analyzed using a sophisticated network analysis methodology.

\subsection{Proteomic-coupled network analysis}

Our ability to capture both liganded and unliganded AR complexes by affinity chromatography under physiological conditions allowed us to pursue a proteomics approach to characterize the components of AR complexes. This can be done by subjecting such complexes to tryptic digestion followed by MS to assign protein identification [95-97]. To our MS data, a label-free quantitative method was also applied for the comparison of peptide abundance across the different experimental paradigms [98, 99].

Therefore, to highlight potentially novel gain-of-function properties associated with mutant $\mathrm{CaP}$ ARs, comparative proteomic characterization studies of AR complexes were done in different experimental backgrounds. To do so, we performed network analysis on individual AR-interacting protein lists derived from our proteomic studies and pursued comparative studies to analyze changes in protein composition based on stimulation condition. We have 
compiled a human protein interaction data from diverse data resources and annotation databases, such as Biomolecular Interaction Network Database (BIND) [100], the Database of Interacting Proteins (DIP) [101], Human Protein Reference Database (HPRD) [102], IntAct [103], and Molecular INTeraction database (MINT) [104], most of which contain curated interaction data and high-throughput data, consisting of 4000 proteins and 22,000 signaling relations/protein interactions.

Quantitative MS data, between stimulation conditions, were used to discern protein abundances. These values were then incorporated into the protein interaction network mapping, to represent a "strength of interaction" coefficient. Between the different experimental conditions, a comparative network analysis was applied [105-108], which was different between our stimulation-specific networks, that is, hierarchical clustering. Immediately what was clear that specific AR protein complexes can be distinguished by the presence or absence of androgen [59]. Analysis of the T877A-AR promiscuous mutant, under different hormone stimulations, showed that although each hormone is able to induce androgen-dependent gene activation [e.g., prostate-specific antigen (PSA)], the proteome profile of each hormone is different. Moreover, although four different androgens were used (DHT, testosterone, MB, and R1881), the proteomic profiles of these androgen ligands do not segregate together. In our hierarchical clustering, we observed that progesterone and dexamethasone AR complexes have proteomic profiles that look like R1881 and MB, respectively [58]. Most recently, analysis of ARv567es protein interactome is very different from androgen stimulated full-length AR (unpublished data), even though ARv567es variant has been characterized as a "constitutively" active receptor $[76,77]$.

From the each AR variant protein interaction network, specific network modules (a set of interacting proteins constituting a subnetwork) are delineated by number of linked interacting proteins interactions and ontological function. The association of subnetwork modules based on biological processes may suggest pathways involved in either tumorigenesis or tumor metastasis. Therefore, to establish statistically significant biological functions, we also implemented the incorporation of Gene Ontological (GO) terms onto each protein the network. We extracted subnetworks in which GO-term-mapped-nodes were directly linked and highlighted subnetworks and pathways to identify gene enrichment of the proteins/genes from a set of clinical prostatic microarray datasets (http://www.ncbi.nlm.nih.gov/geo/) [109, 110] and RNA sequencing (https://tcga-data.nci.nih.gov/tcga/) $[8,111]$. Results show that expression levels of the interacting partners/GO-terms were able to discern normal vs. cancer and correlated with patient survival. More intriguing, different AR protein interaction clusters could differentiate prostatic disease between White (non-Hispanic) vs. African-American males [58]. Nor could we find a gene set that was shared between the two diverse and genetically distinct groups of men. This would suggest that there are AR functional classes that can be used to predict prostatic disease between genetically diverse groups and presumably determine therapeutic modalities. However, the underlining mechanism for these results is not known at this time, although differential population-specific AR activity and disease susceptibility have been very well described clinically [112-115]. Although there have been numerous studies employing microarrays, and recent proteomic screens $[116,117]$, simple single gene or protein analysis is 
inadequate to the study of complexity of disease processes, if conclusions toward clinical outcomes wish to be made. Although several "single" genes and proteins have been identified in these studies that are involved with distinct tumor progression and survival profiles and are proposed as prognostic markers; however, once these genes begin to be analyzed as a combined "cluster" model, they do not to translate into statistically significant results related to clinical specimens. The lack of understanding how these genes and proteins act within their functional context and how these components are integrated into signaling pathways and exist as dynamic complexes to execute distinct programs may be responsible for their failure to predict disease progression.

\subsection{AR: More than a transcription factor}

The above-mentioned work now strongly suggests that the AR functionality extends beyond its classical role as a transcription factor and includes the novel properties of alternative RNA splicing, DNA methylation, proteasomal interaction, and RNA translation at polyribosomes $[58,59]$, with evidence now suggesting that the ARv567es variant may also participate in glucose metabolism (Paliouras and Trifiro, unpublished data). A number of novel ARinteracting partners have been characterized, with the majority having been identified in the proteomic screen. These proteins include, heat-shock protein 27 (HSP27) [118], DDX5 [119], SAM68 [120], deleted in breast cancer 1 (DBC1) [121], minichromosome maintenance 7 (MCM7) [122], $\alpha$-actinin 4 (ACTN4) [116], peroxiredin 1 (PRDX1) [123], DEAD-box polypeptide 17 (DDX17) [124], nucleophosim (NPM1) [125], and Ying Yang 1 (YY1) [126]. Furthermore, these findings point to the complexity of the AR-interacting protein unit and suggest it is involved in a number of different pathways that could function as part of a group of interconnected pathways, whose individual compositions alter depending on AR mutational and stimulation status, to generate the appropriate AR biological output.

\section{Animal models for CaP}

The impact of animal models, especially mouse models, has contributed tremendously to our understanding of tumorigenesis, disease etiology, and drug development. However, one of the difficulties with animals is recapitulating the heterogeneousness of the human cancer. Although mice and other animals do share a high degree of genetic similarity and protein homology, there are still some stark differences in trying to mimic human disease. For use of genetically engineered mouse models (GEMMs), several outstanding issues have arisen for the study of $\mathrm{CaP}$ and include the following: animal life span and correlating disease onset and stages of disease progression to human counterparts; the dissimilarities in prostate organs; diet and nutrition; and assessing clinical relevancy to disease pathology, etiology, and outcomes. For CaP researchers, along with GEMMs, a number of other animal model approaches can also be utilized, including a number of spontaneous non-murine $\mathrm{CaP}$ models, will also be discussed. Moreover, throughout the discussion of assessing $\mathrm{CaP}$ animal models, attempts will be made discuss the role AR continues to make. 


\subsection{Spontaneous non-murine models}

One of the first animal models to study $\mathrm{CaP}$ was in rats. Rats are one of the few animals that develop spontaneous CaP disease [127, 128]. The best studied rat model is the Dunning rat model, which develops slow-growing, well-differentiated, and non-metastatic tumors. Some of the outstanding issues that arise are the rarity of tumors and the variability in the phenotypes. There is also a long latency period in tumor development and a lack of metastasis. However, tumors from Dunning rats are initially androgen dependent and eventually becoming androgen independent. Further refinement of Dunning rats has produced animals that are able to develop highly metastatic tumors that spread to lymph nodes and the lungs [129].

CaP also spontaneously occurs in dogs and most closely resembles humans in terms of disease characteristics [130]. CaP in dogs is age dependent, which ideally allows for the study of disease progression, and, in $24 \%$ of cases, is able to metastasize to bone. DPC-1, CaP cells derived from dogs, have also been observed to potentially display a number of molecular characteristics including androgen-dependent gene profiling with positive prostate-specific antigen (PSA) and prostate-specific membrane antigen (PMSA) expression [131, 132]. The expression of the progressive disease PMSA marker in DPC-1 cells have allowed for the development of directed radiolabeled-PMSA monoclonal antibodies for SPECT/CT imaging [133]. Another dog model, using cells derived from bone metastasis and injected into dogs, could similarly be used for PET imaging [134]. However, tumors do not regress in castrated dogs and thus are androgen independent. As with rats, there is also a relatively long period for tumor development in dogs. However, the high costs, the gestation period, and the difficulty to genetic manipulate the animals make dogs a very difficult model to use experimentally.

\subsection{Genetically engineered mouse models (GEMM) for prostate cancer}

Murine models are also not without their limitations, especially as there has not been a single reported case of mice spontaneously developing $\mathrm{CaP}$ [135]. Mice have the similar limitations as all other animal models that they are significantly thousands of time smaller and live 30-50 times shorter than humans [136]. As such, a great deal of time and effort has been put into genetically manipulating mice so that they do develop $\mathrm{CaP}$ and accurately represent the human disease. However, the human prostate is anatomical different from its mouse counterpart, as the mouse prostate has a lobular structure consisting of four lobes (anterior/ coagulating, ventral, dorsal, and lateral) [137], the human prostate organ is a single lobe divided into three zones (central, transitional, and peripheral), and whether the stroma cells surrounding the mouse lobes is similar in comparison with the human stroma cells. The majority of human $\mathrm{CaP}$ is also found in the peripheral zone. In mice, the dorsal/lateral lobes have been best described as most similar to the human peripheral zone [135, 138]. On closer assessment, human and mouse prostates become more similar, with stroma cells surrounding epithelial cells. The epithelial cell compartment is also comprised by two cell layers (basal and terminally differentiated luminal cells); also, there are populations of epithelial cell precursors and neuroendocrine cells. In mice, basal cells differentiate into luminal and neuroendocrine cells during prostate development $[135,139]$. 
From the first GEMM for prostate cancer (CaP) developed by Greenberg et al., 1994 [140], to the most recent AR splice variant model by Liu et al. [141], no single model accurately encompasses the entire spectrum of human $\mathrm{CaP}$ progression. As $\mathrm{CaP}$ is late onset and slowly developing disease, it would be counterintuitive to experimental design. Thus, criteria need to be considered when using mouse models: (1) should reproducibly recapitulate one or more stages of disease progression; (2) should originate within epithelial cells of the prostate; (3) although ideally progression to invasive adenocarcinoma would be desired, but prostatic intraepithelial neoplasia (PIN) should be observed and display associated pathological criteria such as increased inflammation; (4) should display the molecular pathology observed in human $\mathrm{CaP}$ tumors, this would include gene and protein expression profile changes that are indicative of an androgen responsive tumor; (5) tumor should respond to ADT or castration. Often times in humans, failure to respond to ADT is linked with the emergence of CRPC and is usually associated with increased expression and nuclear localization of AR since CRPC remains dependent on AR signaling [142]; (6) tumors should achieve bone metastasis (common sites of metastasis observed in human patients). Although rare bone metastasis has been observed in some GEMM, visceral (lung and liver) metastasis appears to be most common.

\subsubsection{AR targeted models}

Several attempts have been undertaken to produce a GEMM that targets AR signaling and function. The mouse AR (mAR) shares over $90 \%$ homology with its human ortholog; however, mAR interestingly lacks an expanded CAG-polyglutamine tract, instead mice possess a mixed CAG/CAC-glutamine/histidine tract. One of the first AR-targeted mouse models was to target the overexpression of $\mathrm{mAR}$ to the prostate secretory epithelium, using the prostate-specific and androgen-responsive mouse probasin $(\mathrm{Pb})$ promoter [143]. By 52 weeks, mice developed high-grade prostatic intraepithelial neoplasia (HGPIN) by 52 weeks. Mice also showed increased proliferation in dorsal/lateral and ventral lobes as marked by increased expression of Ki67 proliferation marker. Even with the increased expression/activity of the mAR, it was insufficient to progress prostatic pathology to $\mathrm{CaP}$.

Another group of investigators opted to take into consideration the differences in the genetic polymorphism of the polyglutamine tract between mice and humans and replace exon 1 of the mAR with exon 1 of the human AR [144]. Three transgenic whole knock-in "humanized" AR mice expressing three different polyglutamine tract lengths $(12 \mathrm{Q}, 21 \mathrm{Q}$, and $48 \mathrm{Q})$ were created. As the length of the polyglutamine tract is linked to AR activity and risk for CaP [34, 51], the reasoning behind the three mice was to differentiated disease progression with AR activity. All mice appear to maintain androgen-dependent gene expression, however, do not develop any prostatic pathology, even with the short $12 \mathrm{Q}$ tract mouse. However, when these mice were crossed to TRAMP mice (see below), the length of the polyglutamine tract was linked to the initiation of prostatic tumors, with shorter having higher incidence of tumors vs. longer tracts, which appear to offer a degree of protection in tumor initiation. Of note, researchers also assessed AR mutations of tumors from their 21Q humanized AR crossed to TRAMP mice under a number of different conditions (intact, intact/bicalutamide, intact/flutamide, and castrated). Along with assessing specific somatic mutations (missense, non-sense, small indolent inser- 
tion/deletions), they also assessed changes in the length of polyglutamine tract. They found an average mutation rate of 4.0/10,000 bp of AR coding sequence, with missense mutations accounting for $54.1 \%$ of putative mutations, with a majority of mutations identified in one or two clones per tumor [145]. Half of the mutations identified also were found in the LBD region, as has often been shown to be responsible for promiscuous ligand-binding gain-of-function properties of the receptor $[68,146]$. Contraction of the polyglutamine tract was also assessed, as it is also commonly observed in disease initiation; however, it was not observed. Although this AR mutation rate is higher than reported in clinical samples [39], it does highlight the mutational sensitivity of AR correlated to disease progression.

Recently, a GEMM was created to study the role of the AR splice variant, ARv567es, in CaP development [141]. ARv567es clone was cloned downstream of androgen responsive $\mathrm{Pb}$ promoter, where endogenous mAR would initially drive expression of the ARv567es, then upon castration of the animals, an adequate expression of ARv567es would then continue to expand its own expression. Thus, the investigators would be able to study the influence of ARv567es on the progression of CaP in castrate-resistant state. The coordinate expression of full-length AR and ARv567es variants were able to illicit epithelial hyperplasia by 16 weeks and invasive adenocarcinoma by 52 weeks. Upon castration at 16 weeks, mice were able to maintain nuclear localization of ARv567es and able to develop more aggressive neoplasias than sham controls. Gene expression profiling of tumors from ARv567es castrated mice also suggested that there is an enrichment of oncogenic pathways, including Wnt $/ \beta$-catenin, NFkB, and K-Ras signaling, that have been linked to aggressive CaP.

\subsubsection{TRAMP and LADY}

The first murine prostate cancer models took advantage of some recent advances in the areas of oncogenetics and steroid hormone receptor functionality. As such, the viral SV40 early region, comprised of the large $\mathrm{T}$ antigen (Tag) and small $\mathrm{t}$ antigen, was cloned downstream of the androgen hormone responsive rat $\mathrm{Pb}$ promoter. After selection of lines of animals with higher expression of SV40 early region in the ventral and dorsal lobes, it yielded the transgenic adenocarcinoma mouse prostate (TRAMP) model [140, 147]. TRAMP mice develop progressive forms of $\mathrm{CaP}$, even distant site metastasis. They are characterized with rapid development of PIN by 12 weeks with adenocarcinoma, predominantly in the dorsal/lateral lobes, arising by 24 weeks of age. The mice can also display castrate-resistant disease, where mice castrated at 12 weeks did not affect primary tumor development or metastasis in the majority of mice with $100 \%$ in the lymph and $67 \%$ lung metastasis [148].

The LADY CaP model is similar to the TRAMP model, in that it utilizes, rather than the entire SV40 early region, only the large T antigen under the control of the long 12-kb Pb promoter [149]. These mice also lead to the development of hyperplasia and PIN by 10 weeks, followed by high-grade epithelial dysplasia and adenocarcinoma by 20 weeks. By 33 weeks of age, the mice display metastatic disease to the liver, lung, and bone with a $90 \%$ penetrance [150]. The metastatic tumors are all neuroendocrine type cancers, similar to TRAMP metastatic tumors [151]. 
TRAMP and LADY models also have been used for a number of preclinical drug studies [152161]; however, questions arise Whether a model that develops localized primary prostatic disease between 20 and 24 weeks is a proper representation of human disease evolution? Furthermore, these models can be referred to as "brutish" with the utilization of the SV40 T antigen region; as such a genetic element has never been implicated in human CaP. However, the T antigen has been identified to bind and inhibit TP53 and RB tumor suppressors, the molecular chaperone DNAJ, and complement p300/CBP, while small $t$ antigen has been shown to bind to the phosphatase PP2A and a number of proteins known to contribute to CaP and other neoplasias [162]. Loss-of-function/deletion mutations TP53 [163-166] and RB [167-172] have been linked to CaP progression, and together, DNAJ [173-175] and p300/CBP [87, 176] have also been describe as AR protein complex proteins and shown to be involved in mediating AR signaling [37, 59, 87]. However, even if the TRAMP/LADY models can be considered feedforward models, because of their dependency on AR signaling, to both drive expression of $\mathrm{SV} 40$ through the $\mathrm{Pb}$ promoter and simultaneously potentially contribute to a favorable cellular environment for AR function; the other questions to arise are Whether the molecular pathology of TRAMP/LADY mice share concordance with expression profiles (genes/proteins) found in clinical $\mathrm{CaP}$ specimens from representative disease stages? Currently, the analysis has not been performed.

\subsubsection{PTEN deficiency}

Phosphatase and tensin homolog (PTEN) is an important regulator of the PI3K/AKT signaling pathway and is frequently deleted/mutated in a number of human cancers [177-182]. In CaP, PTEN deletions occur in approximately $23 \%$ of HGPIN, $68 \%$ of localized primary tumors [183], and $86 \%$ of CRPC [184] and thus has become a candidate for developing into a mouse model. Although homozygous knock-out (KO) Pten mice are embryonic lethal, heterozygous Pten ${ }^{+/}$ mice develop a number of neoplasias, including lymphomas, dysplastic intestinal polyps, endometrial complex atypical hyperplasia, and thyroid neoplasia [185]. However, common human tumors, such as brain, breast, and skin, associated with PTEN deletion are absent from mice. Pten ${ }^{+-}$mice also have a spectrum of prostatic phenotypes, with $70 \%$ of mice displaying hyperplasia and dysplasia between 6 and 30 weeks [186]. Using a reduced activity of hypomorphic Pten allele, it has been shown that Pten ${ }^{+/ \text {hyp }}$ mice can promote progression from hyperplasia to PIN between 6 and 22 weeks of age between 25 and $37.5 \%$ of the time, however, with only a single case of adenocarcinoma observed [185, 187, 188].

Due to the latency of prostatic disease development in $\mathrm{Pten}^{+-}$mice, researchers have undertaken to cross these mice with other genes associated with $\mathrm{CaP}$ with the objective to accelerate disease progression. This has included crosses to $\mathrm{p} 27^{\mathrm{Kip} 1}$ and Nkx3.1 loss-of-function allele mouse strains. In 13-22 weeks, Pten ${ }^{+-}$, p27Kip1 ${ }^{-/}$mice develop PIN with $100 \%$ penetrance and about $25 \%$ of mice develop invasive CaP [189]. Alone, Nkx3.1 loss-of-function mice do not develop PIN or CaP in mice; however, in combination with $\mathrm{Pten}^{+/}$mice, they show an accelerated incidence and progression to HGPIN/early carcinoma at 26 weeks, with $100 \%$ penetrance of HGPIN at 52 weeks [190]. By allowing the $\mathrm{Pten}^{+-}$; Nkx3.1 ${ }^{+/-}$mice to age more than 52 weeks, allows HGPIN lesions to progress to invasive adenocarcinoma. Furthermore, 
surgical castration at 24 weeks, of these animals, resulted in partial regression of the prostatic lesions and decreased expression of AR [191].

In 2003, Wang et al., generated a mouse model that specifically deleted exon 5 of Pten in the prostate [192]. These mice developed hyperplasia in 4 weeks, PIN at 6 weeks, and frank adenocarcinoma with $100 \%$ penetrance between 9 and 24 weeks. The mice also respond to surgical castration with an observed increase in apoptosis and extended survival time vs. noncastrated animals. However, castrated animals still maintained prostates 5- to 10-fold larger than WT counterparts and reduced AR expression. Although reduced AR expression is consistent with other Pten deficiency mice, this is not what is observable in human CaP [193]. Additionally, metastasis to the lymph nodes and lungs at 12-29 weeks was observed in 45\% of animals.

Currently, there are a number of prostate-specific conditional Pten $\mathrm{KO}$ mice that have been developed that employ alternative promoters. A PSA-promoter-driven Pten KO resulted in $100 \%$ penetrance of adenocarcinoma and carcinoma by 56 weeks [194]. However, by simultaneously knocking out, Pten and Nkx3.1, coupled with tamoxifen inductions, slowly developed HGPIN with microinvasion [195]. Tumors regress in castrated mice, but then continue to progress to microinvasive adenocarcinoma while maintaining nuclear AR expression, suggesting that AR signaling remains active in the mice following castration. Combinatorial ADT and inhibition of AKT (MK2206) and mTOR (MK8669) function significantly reduced tumor burden [196].

\section{Cell metabolism, ROS, DNA damage, and the AR}

The AR has long been known to have dramatic effects on the prostate gland. The acute withdrawal of androgens lead to severe atrophy of the prostate gland in short time frames originally referred to as involution, which in currently acknowledged as a programmed cell death event [197]. The AR also has significant effects on the overall anabolic and intermediary metabolism, promoting glucose uptake, and pursuing through both the glycolytic, TCA cycle and fatty acid metabolism.

A number of non-genomic influences have been associated with specific risks to the development of $\mathrm{CaP}$, one of these risk factors has been nutrition and diet, especially Western (highfat/low-carbohydrate) vs. non-Western (low fat/high carbohydrate) has been extensively reviewed [198-200]. Likewise, GEMM also have been shown to be influenced by high-fat diets. TRAMP mice given a Western-type diet containing $21.2 \%$ fat and $0.2 \%$ cholesterol vs. regular chow diet $(4.5 \%$ fat and $0.002 \%$ cholesterol), with $33 \%$ of mice showing large and very pronounced tumors at 28 weeks, with increased tumor size and weight and hyperplasia [201]. Western-type fed TRAMP mice also showed increased expression of cell cycle-related (cyclin D1) and proliferation (proliferating cell nuclear antigen-PCNA) markers. There was also an increase in lung metastasis with an average of $3 \pm 1.04$ foci vs. $0.43 \pm 0.2$ foci, in Western-type vs. regular chow-fed mice. Another group also observed similar results with a high-fat diet fed TRAMP mouse [202]. Along with seeing an increase in tumor size and increase prostatic 
hyperplasia, they also observed a decrease in the expression of glutathione peroxidase 3 (GPx3). GPx3 is an important antioxidant enzyme responsible for detoxifying cells of reactive oxygen species (ROS). Increased ROS levels in one of the consequences on high-fat diets and has been shown to interfere with a number of cellular processes, including damaging DNA [203]. GPx3 levels have been shown to be downregulated in CaP [204, 205]. The combinatorial observation that high-fat fed TRAMP mice have larger tumors with cellular changes (increased ROS levels, reduced GPx3 expression) suggests a potential mechanism for a role of cellular metabolism in CaP progression. Increased cellular metabolism and downstream effects of increased ROS levels and DNA damage create the scenario for tumor cells to incur more mutations that may lead to more aggressive tumor growth and drug resistance.

The AR thus has an intrinsic ingrained property of promoting prostatic cellular metabolism. It is not unreasonable that in $\mathrm{CaP}$ initiation and evolution, alterations in AR allowing further enhanced metabolism may be the fundamental mechanisms allowing for new mutations to be created. Heightened metabolism has a direct effect on reactive oxygen species generation (ROS) as hypermetabolism can result in exaggerated mitochondria fluxes [206-211]. It is now well appreciated that cancer metabolism is unique many times demonstrating heightened glucose uptake and abnormal mitochondrial pathways including glutamine lysis and reverse carboxylation. These metabolic properties are not reflective of energy needs and can be considered in conjunction with fatty acid oxidations as a metabolic phenotype-supporting ROS leading to DNA alterations, in essence a powerful mutator phenotype.

\section{Author details}

Miltiadis Paliouras ${ }^{1,2^{*}}$, Carlos Alvarado ${ }^{1,2}$ and Mark Trifiro ${ }^{1,2}$

*Address all correspondence to: miltiadis.paliouras@mcgill.ca

1 Lady Davis Institute for Medical Research, Jewish General Hospital, Montreal, QC, Canada 2 Department of Medicine, McGill University, Montreal, QC, Canada

\section{References}

[1] Forbes SA, Beare D, Gunasekaran P, et al. COSMIC: exploring the world's knowledge of somatic mutations in human cancer. Nucleic Acids Res 2015;43:D805-11.

[2] Forbes SA, Bindal N, Bamford S, et al. COSMIC: mining complete cancer genomes in the Catalogue of Somatic Mutations in Cancer. Nucleic Acids Res 2011;39:D945-50. 
[3] Forbes SA, Tang G, Bindal N, et al. COSMIC (the Catalogue of Somatic Mutations in Cancer): a resource to investigate acquired mutations in human cancer. Nucleic Acids Res 2010;38:D652-7.

[4] Forbes SA, Bhamra G, Bamford S, et al. The Catalogue of Somatic Mutations in Cancer (COSMIC). Current protocols in human genetics / editorial board, Jonathan L Haines [et al] 2008;Chapter 10:10.11.1-.10.11.26.

[5] Forbes S, Clements J, Dawson E, et al. Cosmic 2005. Br J Cancer 2006;94:318-22.

[6] Bamford S, Dawson E, Forbes S, et al. The COSMIC (Catalogue of Somatic Mutations in Cancer) database and website. Br J Cancer 2004;91:355-8.

[7] Wu TJ, Schriml LM, Chen QR, et al. Generating a focused view of disease ontology cancer terms for pan-cancer data integration and analysis. Database (Oxford) 2015;2015:bav032.

[8] Tomczak K, Czerwinska P, Wiznerowicz M. The Cancer Genome Atlas (TCGA): an immeasurable source of knowledge. Contemp Oncol (Pozn) 2015;19:A68-77.

[9] Wu TJ, Shamsaddini A, Pan Y, et al. A framework for organizing cancer-related variations from existing databases, publications and NGS data using a high-performance Integrated Virtual Environment (HIVE). Database (Oxford) 2014;2014:bau022.

[10] Kandoth C, McLellan MD, Vandin F, et al. Mutational landscape and significance across 12 major cancer types. Nature 2013;502:333-9.

[11] Nishant KT, Singh ND, Alani E. Genomic mutation rates: what high-throughput methods can tell us. BioEssays 2009;31:912-20.

[12] Korneliussen TS, Albrechtsen A, Nielsen R. ANGSD: analysis of next generation sequencing data. BMC Bioinformatics 2014;15:356.

[13] Lawrence MS, Stojanov P, Mermel CH, et al. Discovery and saturation analysis of cancer genes across 21 tumour types. Nature 2014;505:495-501.

[14] Pleasance ED, Cheetham RK, Stephens PJ, et al. A comprehensive catalogue of somatic mutations from a human cancer genome. Nature 2010;463:191-6.

[15] Gawad C, Koh W, Quake SR. Single-cell genome sequencing: current state of the science. Nat Rev 2016;17:175-88.

[16] Li SC, Tachiki LM, Kabeer MH, Dethlefs BA, Anthony MJ, Loudon WG. Cancer genomic research at the crossroads: realizing the changing genetic landscape as intratumoral spatial and temporal heterogeneity becomes a confounding factor. Cancer Cell Int 2014;14:115.

[17] Gottlieb B, Alvarado C, Wang C, et al. Making sense of intratumor genetic heterogeneity: altered frequency of androgen receptor CAG repeat length variants in breast cancer tissues. Human Mutat 2013;34:610-8. 
[18] Swanton C. Intratumor heterogeneity: evolution through space and time. Cancer Res 2012;72:4875-82.

[19] Fox EJ, Prindle MJ, Loeb LA. Do mutator mutations fuel tumorigenesis? Cancer Metastasis Rev 2013;32:353-61.

[20] Hanahan D, Weinberg RA. Hallmarks of cancer: the next generation. Cell 2011;144:64674.

[21] Loeb LA. A mutator phenotype in cancer. Cancer Res 2001;61:3230-9.

[22] Loeb LA. Cancer cells exhibit a mutator phenotype. Adv Cancer Res 1998;72:25-56.

[23] Aizawa S, Ohashi M, Loeb LA, Martin GM. Multipotent mutator strain of mouse teratocarcinoma cells. Somat Cell Mol Genet 1985;11:211-6.

[24] Prostate Cancer. In: American Cancer Society; 2012. www.cancer.org/Cancer/ProstateCancer/DetailedGuide/prostate-cancer-what-causes

[25] Draisma G, Etzioni R, Tsodikov A, et al. Lead time and overdiagnosis in prostatespecific antigen screening: importance of methods and context. J Nat Cancer I 2009;101:374-83.

[26] Andriole GL, Crawford ED, Grubb RL, 3rd, et al. Mortality results from a randomized prostate-cancer screening trial. N Eng J Med 2009;360:1310-9.

[27] Andriole GL, Bostwick DG, Brawley OW, et al. Effect of dutasteride on the risk of prostate cancer. N Eng J Med 2010;362:1192-202.

[28] Guyader C, Ceraline J, Gravier E, et al. Risk of hormone escape in a human prostate cancer model depends on therapy modalities and can be reduced by tyrosine kinase inhibitors. PLoS One 2012;7:e42252.

[29] Linja MJ, Visakorpi T. Alterations of androgen receptor in prostate cancer. J Steroid Biochem Mol Biol 2004;92:255-64.

[30] Brimo F, Xu B, Scarlata E, et al. Biopsy characteristics in men with a preoperative diagnosis of prostatic adenocarcinoma with high Gleason score (8-10) predict pathologic outcome in radical prostatectomy. Hum Pathol 2014;45:2006-13.

[31] Marquard J, Eng C. Multiple endocrine Neoplasia type 2. In: Pagon RA, Adam MP, Ardinger $\mathrm{HH}$, et al., eds. GeneReviews(R). Seattle, WA: University of Washington, 1993.

[32] Steinmetz AC, Renaud JP, Moras D. Binding of ligands and activation of transcription by nuclear receptors. Ann Rev Biophys Biomol Struct 2001;30:329-59.

[33] Whitfield GK, Jurutka PW, Haussler CA, Haussler MR. Steroid hormone receptors: evolution, ligands, and molecular basis of biologic function. J Cell Biochem 1999;(Suppl 32-33):110-22. 
[34] Casella R, Maduro MR, Lipshultz LI, Lamb DJ. Significance of the polyglutamine tract polymorphism in the androgen receptor. Urology 2001;58:651-6.

[35] Gao W, Bohl CE, Dalton JT. Chemistry and structural biology of androgen receptor. Chem Rev 2005;105:3352-70.

[36] Gobinet J, Poujol N, Sultan C. Molecular action of androgens. Mol Cell Endocrinol 2002;198:15-24.

[37] Gottlieb B, Beitel LK, Nadarajah A, Paliouras M, Trifiro M. The androgen receptor gene mutations database: 2012 update. Human Mutat 2012;33:887-94.

[38] Gottlieb B, Beitel LK, Wu JH, Trifiro M. The androgen receptor gene mutations database (ARDB): 2004 update. Human Mutat 2004;23:527-33.

[39] Robinson D, Van Allen EM, Wu YM, et al. Integrative clinical genomics of advanced prostate cancer. Cell 2015;161:1215-28.

[40] Cooper CS, Eeles R, Wedge DC, et al. Analysis of the genetic phylogeny of multifocal prostate cancer identifies multiple independent clonal expansions in neoplastic and morphologically normal prostate tissue. Nat Genet 2015;47:367-72.

[41] Boutros PC, Fraser M, Harding NJ, et al. Spatial genomic heterogeneity within localized, multifocal prostate cancer. Nat Genet 2015;47:736-45.

[42] Wu C, Wyatt AW, Lapuk AV, et al. Integrated genome and transcriptome sequencing identifies a novel form of hybrid and aggressive prostate cancer. J Pathol 2012;227:5361.

[43] Yu MW, Yang YC, Yang SY, et al. Androgen receptor exon 1 CAG repeat length and risk of hepatocellular carcinoma in women. Hepatology 2002;36:156-63.

[44] Ferro P, Catalano MG, Dell'Eva R, Fortunati N, Pfeffer U. The androgen receptor CAG repeat: a modifier of carcinogenesis? Mol Cell Endocrinol 2002;193:109-20.

[45] Bennett CL, Price DK, Kim S, et al. Racial variation in CAG repeat lengths within the androgen receptor gene among prostate cancer patients of lower socioeconomic status. J Clin Oncol 2002;20:3599-604.

[46] Yu MW, Cheng SW, Lin MW, et al. Androgen-receptor gene CAG repeats, plasma testosterone levels, and risk of hepatitis B-related hepatocellular carcinoma. J Nat Cancer Inst 2000;92:2023-8.

[47] Ferro P, Catalano MG, Raineri M, et al. Somatic alterations of the androgen receptor CAG repeat in human colon cancer delineate a novel mutation pathway independent of microsatellite instability. Cancer Genet Cytogenet 2000;123:35-40.

[48] Giovannucci E, Platz EA, Stampfer MJ, et al. The CAG repeat within the androgen receptor gene and benign prostatic hyperplasia. Urology 1999;53:121-5. 
[49] Giovannucci E, Stampfer MJ, Krithivas K, et al. The CAG repeat within the androgen receptor gene and its relationship to prostate cancer. Proc Nat Acad Sci USA 1997;94:3320-3.

[50] Southwell J, Chowdhury SF, Gottlieb B, et al. An investigation into CAG repeat length variation and $\mathrm{N} / \mathrm{C}$ terminal interactions in the T877A mutant androgen receptor found in prostate cancer. J Steroid Biochem Mol Biol 2008;111:138-46.

[51] Palazzolo I, Gliozzi A, Rusmini P, et al. The role of the polyglutamine tract in androgen receptor. J Steroid Biochem Mol Biol 2008;108:245-53.

[52] Sircar K, Gottlieb B, Alvarado C, et al. Androgen receptor CAG repeat length contraction in diseased and non-diseased prostatic tissues. Prostate Cancer Prostatic Dis 2007;10:360-8.

[53] Zhang L, Leeflang EP, Yu J, Arnheim N. Studying human mutations by sperm typing: instability of CAG trinucleotide repeats in the human androgen receptor gene. Nat Genet 1994;7:531-5.

[54] Alvarado C, Beitel LK, Sircar K, Aprikian A, Trifiro M, Gottlieb B. Somatic mosaicism and cancer: a micro-genetic examination into the role of the androgen receptor gene in prostate cancer. Cancer Res 2005;65:8514-8.

[55] Elhaji YA, Stoica I, Dennis S, Purisima EO, Trifiro MA. Impaired helix 12 dynamics due to proline 892 substitutions in the androgen receptor are associated with complete androgen insensitivity. Human Mol Genet 2006;15:921-31.

[56] Nguyen D, Steinberg SV, Rouault E, et al. A G577R mutation in the human AR P box results in selective decreases in DNA binding and in partial androgen insensitivity syndrome. Mol Endocrinol (Baltimore, Md) 2001;15:1790-802.

[57] Beitel LK, Prior L, Vasiliou DM, et al. Complete androgen insensitivity due to mutations in the probable alpha-helical segments of the DNA-binding domain in the human androgen receptor. Human Mol Genet 1994;3:21-7.

[58] Zaman N, Giannopoulos PN, Chowdhury S, et al. Proteomic-coupled-network analysis of T877A-androgen receptor interactomes can predict clinical prostate cancer outcomes between White (non-Hispanic) and African-American groups. PLoS One 2014;9:e113190.

[59] Paliouras M, Zaman N, Lumbroso R, et al. Dynamic rewiring of the androgen receptor protein interaction network correlates with prostate cancer clinical outcomes. Integr Biol 2011;10:1020-32.

[60] Bielas JH, Loeb KR, Rubin BP, True LD, Loeb LA. Human cancers express a mutator phenotype. Proc Nat Acad Sci USA 2006;103:18238-42.

[61] Venkatesan RN, Bielas JH, Loeb LA. Generation of mutator mutants during carcinogenesis. DNA Repair (Amst) 2006;5:294-302. 
[62] Isaacs JT, Isaacs WB. Androgen receptor outwits prostate cancer drugs. Nat Med 2004;10:26-7.

[63] Taplin ME, Balk SP. Androgen receptor: a key molecule in the progression of prostate cancer to hormone independence. J Cell Biochem 2004;91:483-90.

[64] Culig Z, Hobisch A, Bartsch G, Klocker H. Androgen receptor-an update of mechanisms of action in prostate cancer. Urol Res 2000;28:211-9.

[65] Hobisch A, Culig Z, Radmayr C, Bartsch G, Klocker H, Hittmair A. Distant metastases from prostatic carcinoma express androgen receptor protein. Cancer Res 1995;55:306872 .

[66] Koivisto P, Kononen J, Palmberg C, et al. Androgen receptor gene amplification: a possible molecular mechanism for androgen deprivation therapy failure in prostate cancer. Cancer Res 1997;57:314-9.

[67] Chang CY, McDonnell DP. Evaluation of ligand-dependent changes in AR structure using peptide probes. Mol Endocrinol (Baltimore, Md) 2002;16:647-60.

[68] Veldscholte J, Ris-Stalpers C, Kuiper GG, et al. A mutation in the ligand binding domain of the androgen receptor of human LNCaP cells affects steroid binding characteristics and response to anti-androgens. Biochemical and biophysical research communications 1990;173:534-40.

[69] Duff J, McEwan IJ. Mutation of histidine 874 in the androgen receptor ligand-binding domain leads to promiscuous ligand activation and altered p160 coactivator interactions. Mol Endocrinol (Baltimore, Md) 2005;19:2943-54.

[70] Vogelstein B, Kinzler KW. The Genetic Basis of Human Cancer. 2nd ed. New York: McGraw-Hill, Medical Publication Division; 2002.

[71] Ceraline J, Cruchant MD, Erdmann E, et al. Constitutive activation of the androgen receptor by a point mutation in the hinge region: a new mechanism for androgenindependent growth in prostate cancer. Int J Cancer 2004;108:152-7.

[72] Taplin ME, Bubley GJ, Ko YJ, et al. Selection for androgen receptor mutations in prostate cancers treated with androgen antagonist. Cancer Res 1999;59:2511-5.

[73] Taplin ME, Bubley GJ, Shuster TD, et al. Mutation of the androgen-receptor gene in metastatic androgen-independent prostate cancer. N Eng J Med 1995;332:1393-8.

[74] Taplin ME, Rajeshkumar B, Halabi S, et al. Androgen receptor mutations in androgenindependent prostate cancer: cancer and Leukemia Group B study 9663. J Clin Oncol 2003;21:2673-8.

[75] Korpal M, Korn JM, Gao X, et al. An F876L mutation in androgen receptor confers genetic and phenotypic resistance to MDV3100 (enzalutamide). Cancer Discov 2013;3:1030-43. 
[76] $\mathrm{Hu} \mathrm{R}, \mathrm{Lu} \mathrm{C}$, Mostaghel EA, et al. Distinct transcriptional programs mediated by the ligand-dependent full-length androgen receptor and its splice variants in castration-resistant prostate cancer. Cancer Res 2012;72:3457-62.

[77] Watson PA, Chen YF, Balbas MD, et al. Constitutively active androgen receptor splice variants expressed in castration-resistant prostate cancer require full-length androgen receptor. Proc Nat Acad Sci USA 2010;107:16759-65.

[78] Sun S, Sprenger CC, Vessella RL, et al. Castration resistance in human prostate cancer is conferred by a frequently occurring androgen receptor splice variant. J Clin Invest 2010;120:2715-30.

[79] Li Y, Hwang TH, Oseth LA, et al. AR intragenic deletions linked to androgen receptor splice variant expression and activity in models of prostate cancer progression. Oncogene 2012;31:4759-67.

[80] Brand LJ, Dehm SM. Androgen receptor gene rearrangements: new perspectives on prostate cancer progression. Curr Drug Targets 2013;14:441-9.

[81] Li Y, Alsagabi M, Fan D, Bova GS, Tewfik AH, Dehm SM. Intragenic rearrangement and altered RNA splicing of the androgen receptor in a cell-based model of prostate cancer progression. Cancer Res 2011;71:2108-17.

[82] Liu LL, Xie N, Sun S, Plymate S, Mostaghel E, Dong X. Mechanisms of the androgen receptor splicing in prostate cancer cells. Oncogene 2014;33:3140-50.

[83] Lu ZX, Huang Q, Park JW, et al. Transcriptome-wide landscape of pre-mRNA alternative splicing associated with metastatic colonization. Mol Cancer Res 2015;13:30518.

[84] Carpenter RL, Lo HW. Identification, functional characterization, and pathobiological significance of GLI1 isoforms in human cancers. Vitamins Horm 2012;88:115-40.

[85] Rajan P, Elliott DJ, Robson CN, Leung HY. Alternative splicing and biological heterogeneity in prostate cancer. Nat Rev Urol 2009;6:454-60.

[86] Venables JP. Aberrant and alternative splicing in cancer. Cancer Res 2004;64:7647-54.

[87] Heemers HV, Tindall DJ. Androgen receptor (AR) coregulators: a diversity of functions converging on and regulating the AR transcriptional complex. Endocr Rev 2007;28:778808.

[88] Paliouras M, Diamandis EP. An AKT activity threshold regulates androgen-dependent and androgen-independent PSA expression in prostate cancer cell lines. Biol Chem 2008;389:773-80.

[89] Paliouras M, Diamandis EP. Intracellular signaling pathways regulate hormonedependent kallikrein gene expression. Tumour Biol 2008;29:63-75. 
[90] Doesburg P, Kuil CW, Berrevoets CA, et al. Functional in vivo interaction between the amino-terminal, transactivation domain and the ligand binding domain of the androgen receptor. Biochemistry 1997;36:1052-64.

[91] Rao J, Lee P, Benzeno S, et al. Functional interaction of human Cdc37 with the androgen receptor but not with the glucocorticoid receptor. J Biol Chem 2001;276:5814-20.

[92] Sharma M, Zarnegar M, Li X, Lim B, Sun Z. Androgen receptor interacts with a novel MYST protein, HBO1. J Biol Chem 2000;275:35200-8.

[93] Beitel LK, Sabbaghian N, Alarifi A, Alvarado C, Pinsky L, Trifiro M. Characterization of normal and point-mutated human androgen receptors expressed in the baculovirus system. J Mol Endocr 1995;15:117-28.

[94] Panet-Raymond V, Gottlieb B, Beitel LK, et al. Characterization of intracellular aggregates using fluorescently-tagged polyglutamine-expanded androgen receptor. Neurotoxicity Res 2001;3:259-75.

[95] Mann M, Hendrickson RC, Pandey A. Analysis of proteins and proteomes by mass spectrometry. Annu Rev Biochem 2001;70:437-73.

[96] Parker CE, Warren MR, Loiselle DR, Dicheva NN, Scarlett CO, Borchers CH. Identification of components of protein complexes. Methods Mol Biol 2005;301:11751.

[97] Kaboord B, Perr M. Isolation of proteins and protein complexes by immunoprecipitation. Methods Mol Biol 2008;424:349-64.

[98] Saba J, Bonneil E, Pomies C, Eng K, Thibault P. Enhanced sensitivity in proteomics experiments using FAIMS coupled with a hybrid linear ion trap/orbitrap mass spectrometer. J Proteome Res 2009;8:3355-66.

[99] Kearney P, Thibault P. Bioinformatics meets proteomics-bridging the gap between mass spectrometry data analysis and cell biology. J Bioinform Comput Biol 2003;1:183200.

[100] Alfarano C, Andrade CE, Anthony K, et al. The biomolecular interaction network database and related tools 2005 update. Nucleic Acids Res 2005;33:D418-24.

[101] Salwinski L, Miller CS, Smith AJ, Pettit FK, Bowie JU, Eisenberg D. The database of interacting proteins: 2004 update. Nucleic Acids Res 2004;32:D449-51.

[102] Peri S, Navarro JD, Amanchy R, et al. Development of human protein reference database as an initial platform for approaching systems biology in humans. Genome Res 2003;13:2363-71.

[103] Hermjakob H, Montecchi-Palazzi L, Lewington C, et al. IntAct: an open source molecular interaction database. Nucleic Acids Res 2004;32:D452-5. 
[104] Zanzoni A, Montecchi-Palazzi L, Quondam M, Ausiello G, Helmer-Citterich M, Cesareni G. MINT: a molecular INTeraction database. FEBS Lett 2002;513:135-40.

[105] Awan A, Bari H, Yan F, et al. Regulatory network motifs and hotspots of cancer genes in a mammalian cellular signalling network. IET Syst Biol 2007;1:292-7.

[106] Cui Q, Ma Y, Jaramillo M, et al. A map of human cancer signaling. Mol Syst Biol 2007;3:152.

[107] Cui Q, Yu Z, Purisima EO, Wang E. Principles of microRNA regulation of a human cellular signaling network. Mol Syst Biol 2006;2:46.

[108] Kelley BP, Yuan B, Lewitter F, Sharan R, Stockwell BR, Ideker T. PathBLAST: a tool for alignment of protein interaction networks. Nucleic Acids Res 2004;32:W83-8.

[109] Clough E, Barrett T. The gene expression omnibus database. Methods Mol Biol 2016;1418:93-110.

[110] Barrett T, Wilhite SE, Ledoux P, et al. NCBI GEO: archive for functional genomics data sets - update. Nucleic Acids Res 2013;41:D991-5.

[111] Chin L, Andersen JN, Futreal PA. Cancer genomics: from discovery science to personalized medicine. Nat Med 2011;17:297-303.

[112] Abern MR, Bassett MR, Tsivian M, et al. Race is associated with discontinuation of active surveillance of low-risk prostate cancer: Results from the Duke Prostate Center. Prostate cancer and prostatic diseases 2012;16:85-90.

[113] Fukagai T, Namiki T, Carlile RG, Namiki M. Racial differences in clinical outcome after prostate cancer treatment. Methods Mol Biol 2009;472:455-66.

[114] Penson DF, Albertsen PC. Lessons learnt about early prostate cancer from large scale databases: population-based pearls of wisdom. Surg Oncol 2002;11:3-11.

[115] Powell IJ. Prostate cancer in the African American: is this a different disease? Semin Urol Oncol 1998;16:221-6.

[116] Jasavala R, Martinez H, Thumar J, et al. Identification of putative androgen receptor interaction protein modules: cytoskeleton and endosomes modulate androgen receptor signaling in prostate cancer cells. Mol Cell Proteomics 2007;6:252-71.

[117] Garbis SD, Tyritzis SI, Roumeliotis T, et al. Search for potential markers for prostate cancer diagnosis, prognosis and treatment in clinical tissue specimens using amine-specific isobaric tagging (iTRAQ) with two-dimensional liquid chromatography and tandem mass spectrometry. J Proteome Res 2008;7:3146-58. 
[118] Zoubeidi A, Zardan A, Beraldi E, et al. Cooperative interactions between androgen receptor (AR) and heat-shock protein 27 facilitate AR transcriptional activity. Cancer Res 2007;67:10455-65.

[119] Clark EL, Coulson A, Dalgliesh C, et al. The RNA helicase p68 is a novel androgen receptor coactivator involved in splicing and is overexpressed in prostate cancer. Cancer Res 2008;68:7938-46.

[120] Rajan P, Gaughan L, Dalgliesh C, et al. The RNA-binding and adaptor protein Sam68 modulates signal-dependent splicing and transcriptional activity of the androgen receptor. J Pathol 2008;215:67-77.

[121] Fu J, Jiang J, Li J, et al. The deleted in breast cancer 1 (DBC-1): A novel AR coactivator that promotes AR DNA binding activity. The Journal of biological chemistry 2009;284:6832-40.

[122] Shi YK, Yu YP, Zhu ZH, et al. MCM7 interacts with androgen receptor. Am J Pathol 2008;173:1758-67.

[123] Park SY, Yu X, Ip C, Mohler JL, Bogner PN, Park YM. Peroxiredoxin 1 interacts with androgen receptor and enhances its transactivation. Cancer Res 2007;67:9294-303.

[124] Wong HY, Demmers JA, Bezstarosti K, Grootegoed JA, Brinkmann AO. DNA dependent recruitment of DDX17 and other interacting proteins by the human androgen receptor. Biochimica et Biophysica Acta 2009;1794:193-8.

[125] Leotoing L, Meunier L, Manin M, et al. Influence of nucleophosmin/B23 on DNA binding and transcriptional activity of the androgen receptor in prostate cancer cell. Oncogene 2008;27:2858-67.

[126] Deng Z, Wan M, Cao P, Rao A, Cramer SD, Sui G. Yin Yang 1 regulates the transcriptional activity of androgen receptor. Oncogene 2009;28:3746-57.

[127] Pollard M. Spontaneous prostate adenocarcinomas in aged germfree Wistar rats. J Nat Cancer I 1973;51:1235-41.

[128] Dunning WF. Prostate cancer in the rat. Nat Cancer Inst Monogr 1963;12:351-69.

[129] Isaacs JT, Weissman RM, Coffey DS, Scott WW. Concepts in prostatic cancer biology: dunning R-3327 H, HI, and AT tumors. Prog Clin Biol Res 1980;37:311-23.

[130] Leroy BE, Northrup N. Prostate cancer in dogs: comparative and clinical aspects. Vet J 2009;180:149-62.

[131] Anidjar M, Scarlata E, Cury FL, et al. Refining the orthotopic dog prostate cancer (DPC)-1 model to better bridge the gap between rodents and men. The Prostate 2012;72:752-61. 
[132] Anidjar M, Villette JM, Devauchelle P, et al. In vivo model mimicking natural history of dog prostate cancer using DPC-1, a new canine prostate carcinoma cell line. The Prostate 2001;46:2-10.

[133] Chevalier S, Moffett S, Turcotte E, et al. The dog prostate cancer (DPC-1) model: a reliable tool for molecular imaging of prostate tumors and metastases. EJNMMI Res 2015;5:77.

[134] Keller JM, Schade GR, Ives K, et al. A novel canine model for prostate cancer. The Prostate 2013;73:952-9.

[135] Shappell SB, Thomas GV, Roberts RL, et al. Prostate pathology of genetically engineered mice: definitions and classification. The consensus report from the Bar Harbor meeting of the Mouse Models of Human Cancer Consortium Prostate Pathology Committee. Cancer Res 2004;64:2270-305.

[136] Rangarajan A, Weinberg RA. Opinion: Comparative biology of mouse versus human cells: modelling human cancer in mice. Nat Rev Cancer 2003;3:952-9.

[137] Abate-Shen C, Shen MM. Mouse models of prostate carcinogenesis. Trends Genet: TIG 2002;18:S1-5.

[138] Powell WC, Cardiff RD, Cohen MB, Miller GJ, Roy-Burman P. Mouse strains for prostate tumorigenesis based on genes altered in human prostate cancer. Curr Drug Targets 2003;4:263-79.

[139] Ousset M, Van Keymeulen A, Bouvencourt G, et al. Multipotent and unipotent progenitors contribute to prostate postnatal development. Nat Cell Biol 2012;14:11318.

[140] Greenberg NM, DeMayo FJ, Sheppard PC, et al. The rat probasin gene promoter directs hormonally and developmentally regulated expression of a heterologous gene specifically to the prostate in transgenic mice. Mol Endocrinol 1994;8:230-9.

[141] Liu G, Sprenger C, Sun S, et al. AR variant ARv567es induces carcinogenesis in a novel transgenic mouse model of prostate cancer. Neoplasia 2013;15:1009-17.

[142] Vis AN, Schroder FH. Key targets of hormonal treatment of prostate cancer. Part 1: the androgen receptor and steroidogenic pathways. BJU international 2009;104:438-48.

[143] Stanbrough M, Leav I, Kwan PW, Bubley GJ, Balk SP. Prostatic intraepithelial neoplasia in mice expressing an androgen receptor transgene in prostate epithelium. Proc Nat Acad Sci USA 2001;98:10823-8.

[144] Albertelli MA, Scheller A, Brogley M, Robins DM. Replacing the mouse androgen receptor with human alleles demonstrates glutamine tract length-dependent effects on physiology and tumorigenesis in mice. Mol Endocrinol (Baltimore, Md) 2006;20:124860 . 
[145] O’Mahony OA, Steinkamp MP, Albertelli MA, Brogley M, Rehman H, Robins DM. Profiling human androgen receptor mutations reveals treatment effects in a mouse model of prostate cancer. Mol Cancer Res: MCR 2008;6:1691-701.

[146] Thin TH, Wang L, Kim E, Collins LL, Basavappa R, Chang C. Isolation and characterization of androgen receptor mutant, AR(M749L), with hypersensitivity to 17-beta estradiol treatment. J Biol Chem 2003;278:7699-708.

[147] Greenberg NM, DeMayo F, Finegold MJ, et al. Prostate cancer in a transgenic mouse. Proc Nat Acad Sci USA 1995;92:3439-43.

[148] Gingrich JR, Barrios RJ, Morton RA, et al. Metastatic prostate cancer in a transgenic mouse. Cancer Res 1996;56:4096-102.

[149] Kasper S, Sheppard PC, Yan Y, et al. Development, progression, and androgendependence of prostate tumors in probasin-large $\mathrm{T}$ antigen transgenic mice: a model for prostate cancer. Lab Invest J Tech Methods Pathol 1998;78:i-xv.

[150] Klezovitch O, Chevillet J, Mirosevich J, Roberts RL, Matusik RJ, Vasioukhin V. Hepsin promotes prostate cancer progression and metastasis. Cancer Cell 2004;6:185-95.

[151] Chiaverotti T, Couto SS, Donjacour A, et al. Dissociation of epithelial and neuroendocrine carcinoma lineages in the transgenic adenocarcinoma of mouse prostate model of prostate cancer. Am J Pathol 2008;172:236-46.

[152] Wada S, Jackson CM, Yoshimura K, et al. Sequencing CTLA-4 blockade with cell-based immunotherapy for prostate cancer. J Transl Med 2013;11:89.

[153] Mueller M, Reichardt W, Koerner J, Groettrup M. Coencapsulation of tumor lysate and CpG-ODN in PLGA-microspheres enables successful immunotherapy of prostate carcinoma in TRAMP mice. J Control Release 2012;162:159-66.

[154] Kang BH, Tavecchio M, Goel HL, et al. Targeted inhibition of mitochondrial Hsp90 suppresses localised and metastatic prostate cancer growth in a genetic mouse model of disease. Br J Cancer 2011;104:629-34.

[155] Zierhut ML, Yen YF, Chen AP, et al. Kinetic modeling of hyperpolarized 13C1-pyruvate metabolism in normal rats and TRAMP mice. J Magn Reson 2010;202:85-92.

[156] Young JG, Green NK, Mautner V, Searle PF, Young LS, James ND. Combining gene and immunotherapy for prostate cancer. Prostate Cancer Prostatic Dis 2008;11:187-93.

[157] Qian DZ, Wei YF, Wang X, Kato Y, Cheng L, Pili R. Antitumor activity of the histone deacetylase inhibitor MS-275 in prostate cancer models. The Prostate 2007;67:1182-93.

[158] Bao Y, Peng W, Verbitsky A, et al. Human coxsackie adenovirus receptor (CAR) expression in transgenic mouse prostate tumors enhances adenoviral delivery of genes. The Prostate 2005;64:401-7. 
[159] Huss WJ, Lai L, Barrios RJ, Hirschi KK, Greenberg NM. Retinoic acid slows progression and promotes apoptosis of spontaneous prostate cancer. The Prostate 2004;61:142-52.

[160] Martiniello-Wilks R, Dane A, Mortensen E, Jeyakumar G, Wang XY, Russell PJ. Application of the transgenic adenocarcinoma mouse prostate (TRAMP) model for preclinical therapeutic studies. Anticancer Res 2003;23:2633-42.

[161] Kaplan-Lefko PJ, Chen TM, Ittmann MM, et al. Pathobiology of autochthonous prostate cancer in a pre-clinical transgenic mouse model. The Prostate 2003;55:219-37.

[162] Ahuja D, Saenz-Robles MT, Pipas JM. SV40 large T antigen targets multiple cellular pathways to elicit cellular transformation. Oncogene 2005;24:7729-45.

[163] Eastham JA, Stapleton AM, Gousse AE, et al. Association of p53 mutations with metastatic prostate cancer. Clin Cancer Res: An Off J Am Assoc Cancer Res 1995;1:11118 .

[164] Kallakury BV, Figge J, Ross JS, Fisher HA, Figge HL, Jennings TA. Association of p53 immunoreactivity with high gleason tumor grade in prostatic adenocarcinoma. Human Pathol 1994;25:92-7.

[165] Effert PJ, Neubauer A, Walther PJ, Liu ET. Alterations of the P53 gene are associated with the progression of a human prostate carcinoma. J Urol 1992;147:789-93.

[166] Meyers FJ, Gumerlock PH, Chi SG, Borchers H, Deitch AD, deVere White RW. Very frequent p53 mutations in metastatic prostate carcinoma and in matched primary tumors. Cancer 1998;83:2534-9.

[167] Jarrard DF, Sarkar S, Shi Y, et al. p16/pRb pathway alterations are required for bypassing senescence in human prostate epithelial cells. Cancer Res 1999;59:2957-64.

[168] Tan HL, Sood A, Rahimi HA, et al. Rb loss is characteristic of prostatic small cell neuroendocrine carcinoma. Clin Cancer Res: An Off J Am Assoc Cancer Res 2014;20:890-903.

[169] Tricoli JV, Gumerlock PH, Yao JL, et al. Alterations of the retinoblastoma gene in human prostate adenocarcinoma. Genes Chromosomes Cancer 1996;15:108-14.

[170] Kubota Y, Fujinami K, Uemura H, et al. Retinoblastoma gene mutations in primary human prostate cancer. The Prostate 1995;27:314-20.

[171] Brooks JD, Bova GS, Isaacs WB. Allelic loss of the retinoblastoma gene in primary human prostatic adenocarcinomas. The Prostate 1995;26:35-9.

[172] Bookstein R, Rio P, Madreperla SA, et al. Promoter deletion and loss of retinoblastoma gene expression in human prostate carcinoma. Proc Nat Acad Sci USA 1990;87:7762-6.

[173] Fliss AE, Rao J, Melville MW, Cheetham ME, Caplan AJ. Domain requirements of DnaJlike (Hsp40) molecular chaperones in the activation of a steroid hormone receptor. J Biol Chem 1999;274:34045-52. 
[174] Terada K, Yomogida K, Imai T, et al. A type I DnaJ homolog, DjA1, regulates androgen receptor signaling and spermatogenesis. EMBO J 2005;24:611-22.

[175] Caplan AJ, Langley E, Wilson EM, Vidal J. Hormone-dependent transactivation by the human androgen receptor is regulated by a dnaJ protein. J Biol Chem 1995;270:5251-7.

[176] Heemers HV, Sebo TJ, Debes JD, et al. Androgen deprivation increases p300 expression in prostate cancer cells. Cancer Res 2007;67:3422-30.

[177] Xi Y, Chen Y. Oncogenic and therapeutic targeting of PTEN loss in bone malignancies. J Cell Biochem 2015;116:1837-47.

[178] Dean JL, Knudsen KE. The role of tumor suppressor dysregulation in prostate cancer progression. Curr Drug Targets 2013;14:460-71.

[179] Nardella C, Carracedo A, Alimonti A, et al. Differential requirement of mTOR in postmitotic tissues and tumorigenesis. Sci Signal 2009;2:ra2.

[180] Lei Q, Jiao J, Xin L, et al. NKX3.1 stabilizes p53, inhibits AKT activation, and blocks prostate cancer initiation caused by PTEN loss. Cancer Cell 2006;9:367-78.

[181] Zhao H, Dupont J, Yakar S, Karas M, LeRoith D. PTEN inhibits cell proliferation and induces apoptosis by downregulating cell surface IGF-IR expression in prostate cancer cells. Oncogene 2004;23:786-94.

[182] Wu X, Senechal K, Neshat MS, Whang YE, Sawyers CL. The PTEN/MMAC1 tumor suppressor phosphatase functions as a negative regulator of the phosphoinositide 3kinase/Akt pathway. Proc Nat Acad Sci USA 1998;95:15587-91.

[183] Yoshimoto M, Cutz JC, Nuin PA, et al. Interphase FISH analysis of PTEN in histologic sections shows genomic deletions in $68 \%$ of primary prostate cancer and $23 \%$ of highgrade prostatic intra-epithelial neoplasias. Cancer Genet Cytogenet 2006;169:128-37.

[184] Holcomb IN, Young JM, Coleman IM, et al. Comparative analyses of chromosome alterations in soft-tissue metastases within and across patients with castration-resistant prostate cancer. Cancer Res 2009;69:7793-802.

[185] Podsypanina K, Ellenson LH, Nemes A, et al. Mutation of Pten/Mmac1 in mice causes neoplasia in multiple organ systems. Proc Nat Acad Sci USA 1999;96:1563-8.

[186] Di Cristofano A, Pesce B, Cordon-Cardo C, Pandolfi PP. Pten is essential for embryonic development and tumour suppression. Nat Genet 1998;19:348-55.

[187] Backman SA, Ghazarian D, So K, et al. Early onset of neoplasia in the prostate and skin of mice with tissue-specific deletion of Pten. Proc Nat Acad Sci USA 2004;101:1725-30.

[188] Stambolic V, Tsao MS, Macpherson D, Suzuki A, Chapman WB, Mak TW. High incidence of breast and endometrial neoplasia resembling human Cowden syndrome in pten $^{+/}$mice. Cancer Res 2000;60:3605-11. 
[189] Di Cristofano A, De Acetis M, Koff A, Cordon-Cardo C, Pandolfi PP. Pten and p27KIP1 cooperate in prostate cancer tumor suppression in the mouse. Nat Genet 2001;27:2224.

[190] Kim MJ, Cardiff RD, Desai N, et al. Cooperativity of Nkx3.1 and Pten loss of function in a mouse model of prostate carcinogenesis. Proc Nat Acad Sci USA 2002;99:2884-9.

[191] Abate-Shen C, Banach-Petrosky WA, Sun X, et al. Nkx3.1; Pten mutant mice develop invasive prostate adenocarcinoma and lymph node metastases. Cancer Res 2003;63:3886-90.

[192] Wang S, Gao J, Lei Q, et al. Prostate-specific deletion of the murine Pten tumor suppressor gene leads to metastatic prostate cancer. Cancer Cell 2003;4:209-21.

[193] Zhang W, Zhu J, Efferson CL, et al. Inhibition of tumor growth progression by antiandrogens and mTOR inhibitor in a Pten-deficient mouse model of prostate cancer. Cancer Res 2009;69:7466-72.

[194] Ma X, Ziel-van der Made AC, Autar B, et al. Targeted biallelic inactivation of Pten in the mouse prostate leads to prostate cancer accompanied by increased epithelial cell proliferation but not by reduced apoptosis. Cancer Res 2005;65:5730-9.

[195] Ratnacaram CK, Teletin M, Jiang M, Meng X, Chambon P, Metzger D. Temporally controlled ablation of PTEN in adult mouse prostate epithelium generates a model of invasive prostatic adenocarcinoma. Proc Nat Acad Sci USA 2008;105:2521-6.

[196] Floc'h N, Kinkade CW, Kobayashi T, et al. Dual targeting of the Akt/mTOR signaling pathway inhibits castration-resistant prostate cancer in a genetically engineered mouse model. Cancer Res 2012;72:4483-93.

[197] Moore RA. The evolution and involution of the prostate gland. Am J Pathol 1936;12:599-624.

[198] Lin PH, Aronson W, Freedland SJ. Nutrition, dietary interventions and prostate cancer: the latest evidence. BMC Med 2015;13:3.

[199] Cowey S, Hardy RW. The metabolic syndrome: a high-risk state for cancer? Am J Pathol 2006;169:1505-22.

[200] McMillan DC, Sattar N, McArdle CS. ABC of obesity. Obes Cancer. BMJ 2006;333:1109_ 11.

[201] Llaverias G, Danilo C, Wang Y, et al. A Western-type diet accelerates tumor progression in an autochthonous mouse model of prostate cancer. Am J Pathol 2010;177:3180-91.

[202] Chang SN, Han J, Abdelkader TS, et al. High animal fat intake enhances prostate cancer progression and reduces glutathione peroxidase 3 expression in early stages of TRAMP mice. The Prostate 2014;74:1266-77. 
[203] Venkateswaran V, Klotz LH. Diet and prostate cancer: mechanisms of action and implications for chemoprevention. Nat Rev Urol 2010;7:442-53.

[204] Khandrika L, Kumar B, Koul S, Maroni P, Koul HK. Oxidative stress in prostate cancer. Cancer Lett 2009;282:125-36.

[205] Yu YP, Yu G, Tseng G, et al. Glutathione peroxidase 3, deleted or methylated in prostate cancer, suppresses prostate cancer growth and metastasis. Cancer Res 2007;67:8043-50.

[206] Zhang S, Yang C, Yang Z, et al. Homeostasis of redox status derived from glucose metabolic pathway could be the key to understanding the Warburg effect. Am J Cancer Res 2015;5:928-44.

[207] Paschos A, Pandya R, Duivenvoorden WC, Pinthus JH. Oxidative stress in prostate cancer: changing research concepts towards a novel paradigm for prevention and therapeutics. Prostate Cancer Prostatic Dis 2013;16:217-25.

[208] Chetram MA, Bethea DA, Odero-Marah VA, Don-Salu-Hewage AS, Jones KJ, Hinton CV. ROS-mediated activation of AKT induces apoptosis via pVHL in prostate cancer cells. Mol Cell Biochem 2013;376:63-71.

[209] Weinberg F, Hamanaka R, Wheaton WW, et al. Mitochondrial metabolism and ROS generation are essential for Kras-mediated tumorigenicity. Proc Nat Acad Sci USA 2010;107:8788-93.

[210] Yang S, Chintapalli J, Sodagum L, et al. Activated IGF-1R inhibits hyperglycemiainduced DNA damage and promotes DNA repair by homologous recombination. Am J Physiol Renal Phys 2005;289:F1144-52.

[211] Feig DI, Loeb LA. Mechanisms of mutation by oxidative DNA damage: reduced fidelity of mammalian DNA polymerase beta. Biochemistry 1993;32:4466-73. 
